\title{
Toward a Return to Plurality in Arendtian Judgment
}

\author{
Jack E. Marsh Jr.
}

\section{Introduction}

$\mathrm{W}$

ithout further ado: the perplexities surrounding the relation of Arendt's early and late theories of judgment are rooted in her singular commitment to the abiding yet fragile possibility of human freedom. These perplexities are not a function of the theoretical faux paux conventionally ascribed to her by well meaning interpreters and sympathetic critics. Indeed, her work exhibits an admirable, if scandalous, refusal to be reduced to the imperatives of an overdetermined moral-theoretical field, an impertinence I hope to honor in this essay. For example, Seyla Benhabib seek to "resolve" Arendtian "puzzles" through reinscribing them within the neoKantian architectonics of discourse ethics. ${ }^{1}$ Ronald Beiner, by contrast, wonders why Arendt didn't further mine Aristotelian wells in elaborating her own account(s) of judgment. ${ }^{2}$ Herein I will take up these putative ambiguities. Interpreters are undoubtedly correct that decisive ambiguities remain between Arendt's early and late accounts of judgment, but these ambiguities issue from Arendt's own problems, concerns, and project.

In what follows, I take up the problem of judgment from within Arendt's own theoretical fabrics. I begin by recounting orthodox accounts of the ambiguity of judgment in Arendt, clearing away standard prejudices so as to grasp the ambiguity more sharply and from within her own framework. I then do a close reading of her 1971 essay "Thinking and Moral Considerations," the essay that introduces the shift in her thinking on judgment. ${ }^{3}$ After querying the theoretical motives for this shift, I outline the problems Arendt creates from herself on her own terms and not external criteria of foreign moral-theoretical projects. I conclude by outlining the basic characteristics any reconstruction of Arendtian judgment must exhibit, and provide a provisional sketch for such a reconstruction. I suggest that the work of Emmanuel Levinas may give us

1 Seyla Benhabib, "Judgment and the Moral Foundations of Politics in Arendt's Thought," in Political Theory, 16:1 (Feburary 1988), 29-51.

2 Ronald Beiner, "Hannah Arendt on Judging," in Hannah Arendt: Lectures on Kant's Political Philosophy, ed. by Ronald Beiner (Chicago: University of Chicago Press, 1982), 140.

${ }^{3}$ Hannah Arendt, "Thinking and Moral Considerations," in Responsibility and Judgment, ed. by Jerome Kohn (New York: Shocken, 2003), 159-189. [hereafter TM]

(c) 2008 Jack E. Marsh Jr. http:// www.kritike.org/journal/issue_4/marsh_december2008.pdf ISSN 1908- 7330 


\section{RETURN TO PLURALITY}

resources for a "return to plurality," or better, to rethink the ambiguities in Arendt's theory of judgment.

\section{II. “Ambiguities"}

\section{a. Arendt's Two Theories of Judgment}

As the story goes, Arendt gives us two different and possibly incommensurable theories of judgment. As Beiner notes, in her earlier writings such as The Crisis in Culture and Truth in Politics, 5 "Arendt had introduced the notion of judgment to give further grounding to her conception of political action as a plurality of actors acting in concert in a public space."6 Here, judgment is taken from the perspective of the vita activa, Arendt's chief concern since the Human Condition. ${ }^{7}$ Human action is constituted in a peculiar and worldly "space of appearances," a space where a plurality of actors can enter into the potential standpoints of others, where "they can share the world with others through judging what is held in common." 8 In her late writings, beginning with her 1971 essay "Thinking and Moral Considerations" and continued through The Life of the Mind Vol. I \& 2, the emphasis shifts from vita activa to the vita contemplativa, from that of the plurality of actors to the solitary thinker who judges history. Below we will explore possible motivates for this shift in emphasis. The usual gesture following this narrative of division between early/practical and late/contemplative is her apparently puzzling linkage or equation of Aristotelian phronesis with Kantian reflective judgment. As Lasch puts it:

On the one hand, Arendt's defense of judgment as the quintessential political virtue seems to lead to an Aristotelian conception of politics as a branch of practical reason. On the other hand, her appeal to Kant as the source of her ideas about judgment appeals to a very different conception of politics, in which political action has to be grounded, not in the practical arts, but in universal moral principles . . .. Arendt's discussion of judgment, instead of clarifying the difference between ancient and modern conceptions of politics and morality, seems to confuse the two. ${ }^{9}$

\footnotetext{
${ }^{4}$ Hannah Arendt, "The Crisis in Culture," in Between Past and Future: Eight Exercises in Political Thought (New York: Viking, 1968), 197-226.

${ }^{5}$ Hannah Arendt, "Truth and Politics," in Ibid., 227-264.

${ }^{6}$ Beiner, op cit., 93. [hereafter $\mathrm{HC}$ ]

${ }^{7}$ Hannah Arendt, The Human Condition (Chicago: University of Chicago Press, 1998).

${ }^{8}$ Beiner, op cit., 93.

9 Christopher Lasch, "Introduction," in Salmagundi, 60 (1983), xi. Quoted in Benhabib, op cit., 31.
} 
While there remains, no doubt, very specific ambiguities in Arendt's shift in emphasis, her attraction to both Aristotle's phronesis and Kant's reflective judgment are not among them. This apparently problematic linkage is only problematic if Arendt is forced to take sides in contemporary moraltheoretical debates between neo-Kantians and communitarians. This linkage is perfectly comprehensible from within Arendt's own region of concern, and she is able to make such a link because of qualifications she introduces in her critical appropriation of these terms. Both phronesis and reflective judgment involve particulars: how to act in particular situations and how to judge particular objects, persons, or events. Arendt thinks phronesis with reflective judgment precisely to wager a manner of judgment no longer utterly tethered to putatively universal principles and the determinate judgments they demand. We will see why she risks such a radical move. But for now we will simply underline that Arendt's appropriation of Aristotelian phronesis and Kantian reflective judgment is critical.

\section{b. Arendt's singular concern}

The practical world is a space of appearances, with all the uncertainty such a space entails. It is unsurprising that Arendt should be attracted to Aristotle here, insofar as this sphere doesn't admit the contemplative certainty of metaphysics. Yet even practical judgment in Aristotle is figured in terms of what Arendt calls homo faber: the uncertainty he admits is that of applying a known "blueprint" or pattern to the facticity of a real situation. ${ }^{10}$ In the process, Aristotle subjects the free action of politics to the means/ends calculations of the social; politics becomes a means to other goods rather than a good in itself: freedom. As we will see, Arendt explicitly rejects the valorization of habit or tradition in attempts to solve the problems of the modern society and politics. Thus, Beiner's neo-Aristotelian response to Arendtian perplexities is somewhat strained.

The problem of modern totalitarianism and her encounter with Eichmann led Arendt to a conviction that stands in direct conflict with neoAristotelian gestures. In the wake of the problems constitutive of modernity, habit and tradition no longer provide a reliable basis for judgment. It is unsurprising that Arendt should be attracted to Kant here, insofar as the thinking implicated in his reflective judgment does not rely on habit and tradition: it is radically autonomous. Arendt rejects the Kant of the $2^{\text {nd }}$ critique. The separateness of the Kantian principium does not refer, first of all, to a determinate set of universal principles in which to subsume particulars, but rather to thinking itself as an original activity, an activity capable of both generating and criticizing such principles in attendance to the concrete. Thus, Benhabib's neo-Kantian "resolution" to Arendtian perplexities is somewhat strained.

${ }^{10}$ See HC, 195, 301-2. 


\section{RETURN TO PLURALITY}

Aristotle's phronesis and Kant's reflective judgment are only at odds if one is standing in the celebrant's camp. From Arendt's perspective, they refer to an autonomous and concrete thinking, a thinking that opens a notion of exemplary validity that is capable of guiding action and soliciting consensus without introducing the compulsion of either habit or law. In both cases, the particular and the concrete are respected. In both cases, it is the experience of freedom or spontaneity that Arendt is out to preserve. Arendt rejects both habit and law as fundamental loci on which the drama of action and judgment turn. The basis for judgment irrupts in the peculiar activity of thinking and the uncanny sense inscribed in it. The deep ambiguity Arendt leaves us involves her own shift from action to thinking as the climactic "site" of judgment. Rather than evaluate her perplexities in light of how they cohere with other projects, I will seek to analyze them from within her own theoretical fabrics and concern. First, I turn to the text that enacts this shift.

\section{A Reading of Thinking and Moral Consideration}

\section{a. Thinking and the Problem of Evil}

Arendt's motivation for thinking the relation between thinking and the problem of evil is twofold: 1) from her experience in and reporting of the Eichmann trial, and 2) the collapse of religious and metaphysical Weltanschauungen constitutive of modernity. With Eichmann, the commission of evil deeds on a grand scale "could not be traced to any particular wickedness, pathology, or ideological conviction in the doer, whose only personal distinction was a perhaps extraordinary shallowness." 11 What is remarkable in Eichmann is his apparent lack of any intense, personal hatred of Jews, and that he executed the genocidal orders of his superiors without thinking. This event raises Arendt's question:

Is our ability to judge, to tell right from wrong, beautiful from ugly, dependent on our faculty of thought? Do the inability to think and a disastrous failure of conscience coincide? The question that imposed itself was, could the activity of thinking as such, the habit of examining and reflecting upon whatever happens to come to pass . . . [my emphasis]. ${ }^{12}$

To answer these questions, Arendt first turns to the crisis of modernity. The questions "What is thinking?" and "What is evil?" traditionally fell to philosophy and religion. Tradition sought to traverse these questions through the 'two-world' thesis: the distinction between the sensible and supersensible. For a whole set of complex reasons, this distinction is no longer

11 TM, 159.

12 Ibid., 160 
tenable. ${ }^{13}$ The announcements of the death of the god of onto-theology and end of metaphysics are nothing other than the announcement of the death of this distinction. ${ }^{14}$ Yet, Arendt contends, the flight of the nether world of pristine ideality does not entail the flight of thought:

These modern "deaths" of God, of metaphysics, of philosophy, and, by implication, of positivism may be events of great importance, but they are after all thought events, and though they concern most intimately our ways of thinking, they do not concern our ability to think, the sheer fact that man is a thinking being. ${ }^{15}$

Human beings have an irreducible 'inclination,' even a need, to think beyond the limits of knowledge, "to do more with [our] intellectual abilities ... than to use them as instruments for knowing and doing." 16 The Kantian distinction between knowing and thinking, and the desire it implicates, is important for Arendt's question:

If the ability to tell right from wrong should have anything to do with the ability to think, then we must be able to "demand" its exercise in every sane person no matter how erudite or ignorant, how intelligent or stupid he may prove to be. ${ }^{17}$

According to Arendt, the "chief characteristics" of thinking are:

1. Thinking "interrupts all doing, all ordinary activities no matter what they happen to be." When we start thinking, we stop "everything else." Thinking involves solitude, a 'suspension' or break in our involvement in everyday practical life. On this account, the practically constituted, 'ordinary' world of labor, work, and even action precede and endure the activity of thinking. Thinking interrupts "everything else" (the ordinary) and "everything else" interrupts thinking.

320.

13 The rise and crisis of modernity is beyond the scope of this paper. See HC, 248-

${ }^{14}$ It is interesting to note the significance Arendt ascribes to these deaths: "I trust it will [have its advantages] once it has been understood what these "ends" actually mean, not that God has "died" - and obvious absurdity in every respect—but the way God has been thought of for thousands of years is no longer convincing; and not that the old questions which are coeval with the appearance of men on earth have become "meaningless," but that the way they were framed and answered has lost plausibility." Ibid., 161-2. On Arendtian terms, the death of (the) god (of onto-theology) opens the possibility of a new - and perhaps also very old - thinking of the holy.

$$
\begin{aligned}
& 15 \text { Ibid., } 163 . \\
& 16 \text { Ibid. } \\
& { }^{17} \text { Ibid., } 164 . \\
& { }^{18} \text { Ibid. }
\end{aligned}
$$




\section{RETURN TO PLURALITY}

2. Thinking "always deals with objects that are absent, removed from direct sense perception."19 Thought is re-presentational and re-memorial. Imagination and memory allow thought to make present objects or persons that are actually absent in the form of an image. As Arendt says, "when I am thinking, I move outside of the world of appearances . . " "20

3. Thinking is anomic or "out of order." 21 The quest for meaning takes on an "unnatural" character, as though the activity of thinking where somehow contrary to the "human condition." Thinking that refuses to obey practical imperatives, to become instrumental to ulterior purposes, exhibits, as Kant says, a "natural aversion" to letting things lie (as they are).

For Arendt the 'world of appearances' is the only world, and so the 'no-place' of thinking is not another 'true' world before or behind the world of appearances. Genuine thinking involves a passage to the limit. Thinking stations itself at the limits of the ordinary, mundane world of work and labor and the "frozen" significances that support it. Thinking, in its 'no-place,' flirts with the (seemingly) impossible.

Arendt elaborates the consequences of her sketch of thinking to her overall thesis on the connection between the ability and inability to think and the problem of evil:

1) The faculty of thinking must be ascribed to everyone.

2) If the faculty of thought has a "natural aversion" against accepting its own results as "solid axioms," then we cannot expect any definitive moral propositions or commandments, any unquestionable code of conduct (we might say, the knowledge of good and evil is always strained).

3) Thinking deals with invisibles, with the absent, and ultimately with death; as such, thinking is anomic, 'out of order,' unhinged, out of joint (with the world of appearances). ${ }^{22}$

We should note here why Arendt rejects traditional moral theory. In so far as traditional ethics think in terms of 'knowledge,' i.e. given principles or laws under which particulars must be subsumed, it mitigates rather than encourages thinking. Eichmann replaced God or Reason with the Fübrer, but the basic structure of determinate judgment and its attendant priority of Law and obedience remained. Determinate judgment mitigates thinking by subsuming willy-nilly particulars under universals. It forbids distinctions and similitudes that stray from its 'eternal' patterns. Law deals in abstractions and actually short-circuits concrete thinking in the face of a violent and temporal human world marked by contingency and variability.

\footnotetext{
${ }^{19}$ Ibid., 165.

${ }^{20}$ Ibid.

${ }^{21}$ Ibid., 166.

22 Ibid., 166-7.
} 


\section{J. MARSH 101}

\section{b. Socrates: Thinking and Judgment}

Arendt turns to Socrates as model of thinking and its moral potentials in judgment. Socrates (as opposed to Plato) never taught positive doctrines. $\mathrm{He}$ functioned in three, interrelated manners that (putatively) exhibit the internal relation between thinking and judgment.

1. Socrates the gadfly: Socrates shocks his interlocutor from his 'undisturbed sleep.' He rouses his fellow citizens to think by questioning the sense of their received opinions, customs, and habits. This questioning leads to concrete adumbrations of the notion in question (piety, justice, virtue, etc.). This questioning does not lead to a positive resolution, but rather ends in aporia.

2. Socrates as midwife: Socrates purged people of their unexamined prejudices, showing them what they don't know.

3. Socrates the 'electric ray': Socrates 'paralyzes' his interlocutors by inducing them to think, i.e. to interrupt "everything else" in thinking. What looks from the outside to be paralysis is from the inside felt to be the highest state of being alive. Thinking deals "with invisibles and is itself invisible, lacking all the outside manifestation of other activities."23

Socrates shows us that thinking is dangerous, it opens up and can possibly overturn the given:

Thinking inevitably has a destructive, undermining effect on all established criteria, values, measurements for good and evil, in short on those customs and rules of conduct we treat of in morals and ethics. ${ }^{24}$

Thus, the paralysis of thought not only includes the 'stop and think,' the interruption of all other activities, but also introduces uncertainty into the ordinary in breaking open its sedimented implications and tacit assumption. Thinking unsettles rule and custom. This performance of thinking at the limit always entails the danger of nihilism. But as Arendt points out, nihilism is simply the negative image of convention, two sides of a problematic coin. Nihilism results from the desire to "find results which would make further thinking unnecessary." 25 Unthinking negation is still unthinking. Unthinking affirmation of general rules encourages people not to think, but to 'sleep' in conventionalism; here, people never get used to "making up their own minds." 26 Thus, as we hinted above, one can simply substitute new values for old ones, if only it is expressed in a new code of laws. The faster men hold to the old code, the more eager they'll be to assimilate to the new one.

Arendt finally turns to elaborating the explicit tie of thinking to judgment: this quest for meaning in thought as a kind of eros. "Love, by

\footnotetext{
${ }^{23}$ Ibid., 174-5.

${ }^{24}$ Ibid., 175-6.

${ }^{25}$ Ibid., 177-8.

${ }^{26}$ Ibid.
} 


\section{RETURN TO PLURALITY}

desiring what is not there, establishes a relationship with it." ${ }^{27}$ Arendt, here, summons the old Augustinian 'privation theory of evil':

Since the quest is a kind of love or desire, the objects of thought can only be lovable things-beauty, wisdom, justice, etc. Ugliness and evil are excluded by definition from thinking concern ... If thinking dissolves normal, positive concepts into their original meaning, then the same process dissolves these negative "concepts" into their original meaninglessness, into nothing. ${ }^{28}$

Apparently, the desire for meaning is intrinsically 'good,' such that an anomic thinking is 'virtuous' in toto (one is tempted to say, essentially virtuous.) Evil lies in the privation - the absence - of good, and even though thinking consists of paralysis (the absence of doing), in re-presentation (the absence of objects or persons), and in 'no-place' (in absence from the world of appearances), it somehow senses or adduces this privation of 'good' in the world as it is. Thinking is stationed at the limit: the critical 'no-place' that resists fatality. Here lies Arendt's conclusion on the connection between thinking and judgment:

We are left with the conclusion that only the people filled with this eros, this desiring love of wisdom, beauty, and justice, are capable of thought - that is, we are left with Plato's "noble nature" as a pre-requisite for thinking. ${ }^{29}$

Before turning to Arendt's concluding reflection, it is worth noting that in her conclusion, the internal link between thinking and judgment is expressed in terms of a "pre-requisite" or condition for thinking. This expression holds decisive consequences in terms of the limits of thinking itself. If thinking exhibits the remarkable ability to pass to the limit, it also remains conditioned by the 'other' of thought. This alterity must 'itself' be irreducible to being, insofar as the spontaneity of thinking can appropriate and re-present being at and in its leisure. To be sure, the play of shock and rupture between being and thinking ought not be questioned in the face of violent world: we need more thinking, not less, we need judgment, not thoughtlessness; but it is fair to question the 'whence' of questionability. What of the non-violent speech and action of plurality and politics? To derive the capacity of judgment from the activity of thinking is to reduce plurality to unity: everyone must think, and genuine thinking is conditioned by erotic desire, by "reasons need" (some would say, reason's infinite lust for conquest) that all potentially posses. Given Arendt's own critique of the vita contemplativa, we must question the 'location'

$$
\begin{aligned}
& { }^{27} \text { Ibid., } 179 . \\
& { }^{28} \text { Ibid. } \\
& { }^{29} \text { Ibid., } 180 .
\end{aligned}
$$




\section{J. MARSH 103}

of questionability in an utter withdrawal from plurality. Wouldn't the unsettling feature of thinking refer back to a more original 'experience,' to a disequilibrium suffered in concreto? Wouldn't the transactions of imagination and memory in thinking involve a deeper and anomic sensibility? If the anomicity of thinking derives from a manifest lack (in being), to avoid the aforementioned unity, its ability to judge must be conditioned by a deeper sensibility inscribed in the very event of plurality. This issue becomes even more pressing in the wake of Arendt's concluding reflection.

\section{c. The Two-In-One}

Arendt closes her essay with a meditation on Socrates (in)famous utterances:

"It is better to be wronged than to do wrong."

And

It would be better for me that my lyre or a chorus I directed should be out of tune and loud with discord, and that multitudes of men should disagree with me rather than I, being one, should be out of harmony with myself and contradict me. ${ }^{30}$

The first is "a subjective statement, it is better for me to suffer wrong than to do wrong." 31 The second involves the paradox of talking about "being one and therefore not being able to risk getting out of harmony with himself." 32 These statements are not moral precepts, but rather insights that emerge from thought itself. Arendt explains:

This curious thing that I am needs no plurality in order to establish difference; it carries the difference within itself when it says: "I am I." So long as I am conscious, that is, conscious of myself, I am identical with myself only for others to whom I appear as one and the same. For myself, articulating this being-conscious-of-myself, I am inevitably two-in-one ... Human consciousness suggests that difference and otherness . . . are the very conditions for the existence of man's ego... ${ }^{33}$

\footnotetext{
${ }^{30}$ Ibid., 181.

${ }^{31}$ Ibid.

32 Ibid., 182.

${ }^{33}$ Ibid., 184.
} 


\section{RETURN TO PLURALITY}

"What thinking actualizes in its process is the difference given in consciousness." 34 When I am not with others, but with myself in thinking, I carry on a dialogue with myself. The auto-affection of the 'experience' of thought provides the basis for judgment: If you want to think, you better get on well with your private, interior dialogue partner. "It is better to suffer than to do wrong because you can remain the friend of the sufferer; who would want to be the friend of and have to live together with a murderer?" 35 The ability to think is

an ever-present faculty of everybody; by the same token, inability to think ... is the ever-present possibility for everybody ... . to shun that intercourse with oneself whose possibility and importance Socrates first discovered. 36

\section{d. Her Conclusion}

The relation of this thinking to judgment is like the relation of consciousness to conscience: "For the thinking ego and its experience, conscience, which 'fills a man full of obstacles,' is a side effect. And it remains a marginal affair for society at large except in emergencies." 37 Here we find the motive for Arendt's shift to thinking and the vita contemplativa as the site of judgment. As she elsewhere writes:

that human beings be capable of telling right from wrong even when all they have to guide them is their own judgment, which, moreover, happens to be completely at odds with what they must regard as the unanimous opinion of all those around them . . . Those few [Germans] who were still able to tell right from wrong went really only by their own judgments, and they did so freely; there were no rules to be abided by, under which the particular cases with which they were confronted could be subsumed. They had to decide each instance as it arose, because no rules existed for the unprecedented. ${ }^{38}$

In such states of emergency, of total collapse of human decency when social mores and law are turned in the service of evil, the remnant that resists can rely on nothing but their own judgment. Arendt seeks to derive this capacity from the solitude and freedom of thinking activity itself. In such

\footnotetext{
${ }^{34}$ Ibid., 185.

35 Ibid.

36 Ibid., 187-8.

37 Ibid., 188

${ }^{38}$ Hannah Arendt, Eichmann in Jerusalem: A Report on the Banality of Evil (New York: Viking, 1965), 294-5. Quoted in Beiner, op cit., 98.
} 
states of emergency, even solitary thinking takes on the character of political action:

When everybody is swept away unthinkingly by what everybody else does and believes in, those who think are drawn out of hiding because their refusal to join is conspicuous and thereby becomes a kind of action. The purging element in thinking, Socrates' midwifery, ... is political by implication. ${ }^{39}$

This negative, purgative, anomic thinking, the "manifestation of the wind of thought is no knowledge; but the ability to tell right from wrong, beautiful from ugly. And this indeed may prevent catastrophes, at least for myself, in the rare moments when the chips are down." 40

\section{Arendtian Judgment}

\section{a. The Motive}

We see now the motive for her late shift to thinking in developing her theory of judgment. In her experience with Eichmann, and probably the general trauma of the Shoah (not to mention Stalin's purges, Hiroshima, etc.), Arendt saw the need for a radically separate space from which to derive judgment. Her own phenomenology of the vita activa locates in human labor and work a world-sustaining and world-constituting function, they create the conditions necessary for action proper. Social habits and rule-governed work practices produce a relatively durable and stable world on which the free action of politics depends. Her account of world-alienation involves the colonization of public space by the rule-governed work paradigm (the actional equivalent of philosophy in the vita contemplativa) and by the process-character of the labor paradigm (expressed in orthodox Marxism, utilitarian liberalism, and even Nietzsche's will-to-power). Where do we turn when the world 'goes bad'? Whence judgment in extreme cases when there is no longer any public, no free space of appearances in which re-presentative judgments can occur? Arendt finds it in the "winds of thought," in negative Socratic desire and critical interrogation. This wind is a kind of felt resistance, a negative freedom to refuse participation in a corrupt world. If her account of judgment as it relates to plurality involves sensibility and the imagination, that sensibility and imagination remain in this negative account. When plurality and publicity is closed, when the world 'goes bad,' judgment remains and thinking becomes politicized in the negative desire irrupting in the obdurate spontaneity of thinking. It is the separateness and negative quality of this thinking that allows it to remain critical and uncorrupt in a situation of total collapse.

39 TM, 188.

${ }^{40}$ Ibid., 189. 


\section{RETURN TO PLURALITY}

In light of her very appropriate motives, there are few significant details worth observing at the outset. Arendt clearly does not want to derive judgment from either conventional social habit or private aesthetic projects. In the wake of the traumas of modernity, whether in an Aristotelian or Heideggerian inflection, Arendt refuses to derive the basis for judgment from Being in either its calculative-social or poetic-asocial dimensions. Neither does she issue a (neo-Kantian) call to a return to universal moral law. Both moves would involve a return to conventionalism and to abstract thinking whose form involves determinate judgment (or in the case of Heidegger, a depoliticized and re-mythologized, asocial, and aristocratic aesthetics). She precisely turns to the "public intellectual" par excellence: Socrates. Arendt, perhaps ironically, summons the "solitary" thinker who performs thinking publicly. Socrates does not escape from Plato's cave or to Heidegger's hut at Todtnauberg in the face of a crumbling polis, in the face of a world 'gone bad.' He stands and resists and criticizes even under threat of death. He stands as a witness, not to the nether world of forms or the whispers of Being, but to the sensibility and desire of thinking itself. At the time of her death, the first page of her intended third volume of The Life of the Mind lay in her typewriter. The sheet was blank except for the heading "Judging" and two epigraphs:

The victorious cause pleased the gods, but the defeated ones pleased Cato.

And

If I could remove the magic from my path, / and utterly forget all enchanted spells, / Nature, I would stand before you as but a man, / then it would be worth the effort of being a man. ${ }^{41}$

In this light, Beiner and Benhabib somewhat miss Arendt's point. In the early and the late period, Arendt is singularly committed to the abiding yet fragile possibility of human freedom. In the early period, judgment positively draws from and participates in the freedom and spontaneity opened in the plurality and natality of public space, a space of appearance that only operates under constraints designated by plurality itself. This space, nothing less then the world, is a space of experimentation and consensus (i.e. persuasive opinion and action) rather than instantiation and compulsion (i.e. demonstrable truth and the execution of its directives). In the late period, judgment negatively withdraws from social participation in a 'world gone bad,' in a world colonized by compulsory 'truth' and mass enthusiasm. Yet this withdrawal happens "in public" as a refusal and as a purgative negation of the colonizing 'truth.'

Beiner and Benhabib misunderstand Arendt's move here. She precisely does not want to grant a fundamental status to either a morality of

${ }^{41}$ Quoted in Beiner, op cit., 126. The Goethe piece is Beiner's translation. 


\section{J. MARSH 107}

habit and tradition or a morality of universality and law, insofar as it is these sources were implicated in the debacle of the $20^{\text {th }}$ century. Arendt's own phenomenology of action implies that habit and law have their part to play, but there must remain a free space of political action and a critical space of judgment that outstrips them. The Kantian principium of thinking is autonomous qua concrete activity, not as a universal and determinate formal Law. Aristotelian phronesis is appropriate to a space of opinion and exemplary validity, a validity that respects the particular and provides guidance to particular action viz. a kind of mimetic sensibility. Arendtian thought identifies the similar in the dissimilar and vice versa, opening constellations which illumines specific situations and persons in ways that counter or transform prevailing interpretations or conventions. Had she had the chance, Arendt would have no doubt elaborated the precise relationship between the positive and actional and negative and critical (thinking) trajectories of judgment. And given her chosen epigrams, this would have involved a resistance to the re-enchantment of politics viz. truth and mass enthusiasm, would have involved a sensitivity to the 'trash' of history whose desire for mortal happiness and worldly freedom demand preservation from oblivion against the amnesia of 'progress.' She would have returned to those momentary glimmers where utopic human hopes actually irrupted in history: the Paris Commune, the Russian soviets of 1905 and 1917, the Hungarian uprising of 1956, and so forth. ${ }^{42}$ Democratic freedom may be a fragile and tenuous affair, but it remains an abiding possibility.

\section{b. The Problem}

Though Beiner and Benhabib misunderstand Arendt's moves and motives, they are correct that she leaves us with unresolved conundrums. The world-constitutive and sustaining function of work and labor and their relation to plurality is never fully specified by Arendt. She clearly suggests that

Labor and work ... are also rooted in natality insofar as they have the task to provide and preserve the world for, to foresee and reckon with, the constant flux of newcomers who are born into the world as strangers. ${ }^{43}$

It would seem that her own designations of plurality and natality entail certain political and perhaps even ethical responsibilities. There are specific constraints inherent to the structure of plurality 'itself,' or that sensibly irrupt in its very event. Given the world sustaining and constituting function she confers upon labor and work, clarifying the relationship between them and public space would precisely involve positively articulating the function of habit and law in relation to natality and plurality. Though Beiner and Benhabib

\footnotetext{
42 Ibid., 127.

${ }^{43} \mathrm{HC}, 9$.
} 


\section{RETURN TO PLURALITY}

are right in this respect, any rigorous Arendtian position must insist on the secondary and constructed or variable character of this relation. Habit and law are not basic; they are subtended and exceeded by a sensibility informing concrete judgment and an activity capable of real change and novelty.

Aside from external imperatives, Arendt's derivation of judgment from thinking activity introduces a dissonance within her own theoretical fabric. The manifest need for a space of judgment separate from social convention and formal law led her close to the intellectualism she elsewhere criticizes, and criticizes trenchantly. In "resolving" the tension in her account of judgment by way of the vita contemplativa, we are left wondering about the status of plurality. Beiner is surely right in contending:

This resolution ultimately produces consistency, but it is a strained consistency, achieved at the price of excluding any reference to the vita activa within the revised concept of judgment. ${ }^{44}$

As we saw above, it seems that Arendt assumes that solitary thinking still remains conditioned by plurality, without specifying how this is so. Her description of thinking and its relation to Being is one of shock and rupture. Whence the non-violent speech and action of plurality? Arendt's singular commitment to fragile human spontaneity taken with her resolute resistance to the compulsion of habit, a compulsion that opened the possibility of the radical evils of the $20^{\text {th }}$ century, perhaps led her to close, even unwittingly, her earlier insights; such that she fails to precisely specify the manner in which this thinking is affected by others within plurality. It is one thing to say that evil happens with the absence of thinking, quite another to derive the sense of the good from the unity and solitude of thought, a unity and capacity then imputed to everyone. Arendt's move is an essentializing one: "This curious thing that I am needs no plurality in order to establish difference"- - her theory of judgment lapses into idealism, and her derivation of judgment looks almost identical to the tradition she elsewhere criticizes. While she designates this thinking and the judgment it produces in terms of sensibility rather than conceptuality, it is an auto-affective sensibility. The self-affection of thought outstrips the hetero-affection of plurality. Her characterizations of thought are convincing, but only insofar as they can refer back to plurality and are decisively sensitized by it. Judgment doesn't spring whole out of thought, as Hegel would have happily insisted. In designating thinking activity as basic and then deriving judgment from "reasons need," or thoughts unquenchable desire to play with itself, Arendt prioritizes the unity and self-activity of the idealist subject. Arendt assumes that ethics only take the form of law and habit, and that the quest for meaning beyond utility is at odds with the ethical. The anomic quality of thinking is, perhaps, conditioned by an anomic ethical sensibility; the 'no-place' or non-worldliness of thinking is conditioned by its elective

${ }^{44}$ Beiner, op cit., 139. 
responsiveness to its 'other,' in a concrete experience of an 'out of joint' disequilibriation. The 'other-within-the-same' of Arendt's two-in-one is, perhaps, testimony to a pre-original affective 'contact' with the human other one faces in the very event of plurality.

\section{Conclusion}

In conclusion, I want to suggest a strategy for reconstructing Arendtian judgment. We should first stipulate the boundaries of any such reconstruction. Any account of Arendtian judgment must have certain characteristics if it is to remain faithful to her theoretical aims and intuitions. These characteristics can be schematically designated in the following manner, Judgment requires:

1) A basis in sensibility rather than conceptuality.

2) Sufficient 'distance' or separateness necessary for critical disinterestedness.

3) Clear differentiation between ethical (sensibility) and political (imagination), between regions and types of responsibility.

4) A rich capacity to 'think in the place of.'

5) A relative autonomy richly implicated in plurality but capable of free judgment.

My strategy for reconstruction runs something like this, and brings Levinas and Arendt into contact:

Insofar as thinking consists in absence (from the world of appearances), it relies on memory. The activity, spontaneity, and originality of imagination are thus dependent on memory. Thinking retains its critical, anomic, and deconstructive character, but this character is opened by and dependent on a 'pre-original' hetero-affection, a hetero-affection that is implicated in and prior to my own auto-affection in thinking. The 'otherwithin-the-same' of the two-in-one refers to an always prior event of plurality ineluctably conditioning the self. This hetero-affection does not refer to a general law or social habit, but is rather an anomic ethical sensibility. It is first of all ethical, and thus pre-political, insofar as the sense this affection inscribes is an unconditional responsibility for the vulnerable and materially destitute human other. The other exhibits a resistance to reduction to my project or concept, a resistance to utility and law. Their supplicating demand is not the heteronomy of another origin or law (hence, not onto-theological!), the demand irrupts in its powerlessness, precisely in that the other is not sovereign, and powerlessly demands my assistance.

This ethical event of the other is only the first moment. What of all the others? Not only am I responsible to the destitute human other, with the (structural not chronological) entrance of le tiers, I am responsible for the other, even responsible for their responsibility. At this juncture, I substitute myself for the others, I become responsible for their responsibility. Justice requires 


\section{RETURN TO PLURALITY}

thought, measure, history, science, and narrativity; in a word, justice requires language. Here, ethical responsibility is distributed and introduces a standard for "the comparison of incomparable." 45 These standards thus open the possibility of thinking legality and collective habits, but more importantly, it sensitizes the activity of thinking, opens it to the concrete, to the fact that "we are all the same, that is, human, in such a way that nobody is ever the same as anyone else who ever lived, lives, or will live." 46

In this short little phenomenology, we have provisionally described the irruption of pre-political (and pre-original) ethical responsibility viz. memory and sensibility, itself an event of plurality; we have described the transition from the duality and passivity of the first moment to the plurality and activity of the second moment viz. substitution, or an ethical 'in the place of which.' We should underline at this point that we have only introduced the possibility of legality and social habit, rather than have designated their precise place and function. More importantly, ethical sensibility in the transition to plurality takes place precisely in the performance of substitution, of the self's ability to recognize itself by putting itself 'in the place' of others as responsible for their responsibility. No appeal has been made to a general term, a law, or to a social convention. We have summoned only the sensibility of the first duality and its distribution viz. substitution and language. We have described a situation where there is always already plurality. What of the separateness necessary for critical distance and disinterest?

The separateness necessary for disinterestedness irrupts in the radical alterity of the human and vulnerable other. Their absolute resistance to reduction to my concept or project and the unconditioned responsibility it elects me to, in the transition to the social with substitution and language, provides the critical distance to judge in a disinterested manner. So far, we have one leg of the basis for critical judgment: the basis for judgment irrupts in the possibility of 'goodness' opened in responsibility. To demand 'justification' in response to the supplicating demand of the powerless would be an indecency (as Arendt somewhere remarks). It is precisely solidarity with the vanquished, with the "trash" of history, which opens goodness and provides a measure for rightness. But what of Arendtian politics proper?

If ethical responsibility excessively and concretely opens the good and the right viz. sensibility (not cognitively), it is the imagination and Arendtian politics and action that opens the beautiful. (Interestingly, we could correlate ethics with a specific account of the sublime and the political with the beautiful). The passivity of the ethical moment opens and sensitizes the self, and viz. substitution, gives us a way to specify juridical accountability. The transition to politics proper entails limiting the excessive passivity and responsibility of the ethical and the compulsion of the juridical. Plurality is at work even at the level of labor and work. To do justice to the ways that this

${ }^{45}$ Emmanuel Levinas, "Peace and Proximity," in Emmanuel Levinas: Basic Philosophical

Writings, ed. by A. T. Peperzak, et al. (Bloomington: Indiana University Press, 1996), 168.

${ }^{46} \mathrm{HC}, 8$. 


\section{J. MARSH 111}

social responsibility is embodied is to recognize a plurality of traditions and practices that cannot be collapsed into one universal legal code or an allencompassing meta-discourse. The passage to politics involves circumscribing the ethical in opening a moment of responsible freedom. This passage allows us to rigorously distinguish between ethical and political responsibility. Politics proper involves a passage to the non-compulsory and non-violent speech and action of free consensus, to the irreducibly plural space of appearances, to the affirmation of terrestrial life, to the amor mundi, and to possibility of a worldly 'immortality' or greatness.

In times of crises, the 'unworldly' moment of anomic thinking is always already sensitized by an 'unworldly' anomic ethical hetero-affection. Critical judgment is decisively opened by ethical sensibility and the responsible freedom it exercises in disinterested judgment. Again, this responsibility is concrete and affective not abstract and formal. It sides with the victims, and bears witness to those impossible moments where, if for an instant, freedom heralded itself on earth.

It would seem that Levinas and Arendt are almost made for each other. Their respective projects precisely supplement areas of lack in the others. There are, no doubt, areas of incommensurability. But as my little sketch suggests, there is enough complementarity to warrant more serious scrutiny of their proximity.

Department of Philosophy, State University of New York at Binghamton, United States

\section{References}

Arendt, Hannah, Eichmann in Jerusalem: A Report on the Banality of Evil (New York: Viking, 1965). 1998). The Human Condition (Chicago: University of Chicago Press,

, "Thinking and Moral Considerations," in Responsibility and Judgment, ed. by Jerome Kohn (New York: Shocken, 2003).

Beiner, Ronald, "Hannah Arendt on Judging," in Hannah Arendt: Lectures on Kant's Political Pbilosophy, ed. by Ronald Beiner (Chicago: University of Chicago Press, 1982).

Benhabib, Seyla, "Judgment and the Moral Foundations of Politics in Arendt's Thought," in Political Theory, 16:1(Feburary 1988), 29-51.

Lasch, Christopher, "Introduction," in Salmagundi, 60 (1983): vii-viii.

Levinas, Emmanuel, "Peace and Proximity," in Emmanuel Levinas: Basic Philosophical Writings, ed. by A. T. Peperzak, et al. (Bloomington: Indiana University Press, 1996). 